\title{
Optimization of spin-coated electrodes for electrolyte-supported solid oxide fuel cells
}

\author{
Shayenne Diniz da Nobrega ${ }^{1}$, Natalia Kondo Monteiro ${ }^{1}$, \\ Francisco Tabuti ${ }^{1}$, Daniel Zanetti de Florio ${ }^{2}$, \\ Fabio Coral Fonseca ${ }^{1}$
}

\author{
${ }^{1}$ Instituto de Pesquisas Energéticas e Nucleares, IPEN-CNEN/SP, 05508-000, São Paulo, SP, Brazil \\ e-mail: shaynnedn@hotmail.com; nataliakm@usp.br; fntabuti@ipen.br; fabiocf@usp.br \\ ${ }^{2}$ Universidade Federal do ABC, 09090-400, Santo André, SP, Brazil \\ e-mail: daniel.florio@ufabc.edu.br
}

\begin{abstract}
Electrodes for electrolyte-supported solid oxide fuel cells (SOFC's) were fabricated by spin coating. Strontium-doped lanthanum manganite (LSM) cathode and nickel yttria-stabilized zirconia cermet anodes were synthesized and processed for enhanced deposition conditions. The influence of electrode microstructural parameters was investigated by a systematic experimental procedure aiming at optimized electrochemical performance of single cells. Polarization curves showed a strong dependence on both electrode thickness and sintering temperature. By a systematic control of such parameters, the performance of single cells was significantly enhanced due to decreasing of polarization resistance from $26 \Omega \mathrm{cm}^{2}$ to $0.6 \Omega \mathrm{cm}^{2}$ at $800^{\circ} \mathrm{C}$. The results showed that spin-coated electrodes can be optimized for fast and cost effective fabrication of SOFCs.
\end{abstract}

Keywords: solid oxide fuel cell; spin-coating; optimization; performance.

\section{INTRODUCTION}

Solid oxide fuel cells (SOFCs) are envisioned as a promising technology for electric power generation with low environmental impact and high efficiency [1]. Such electrochemical energy converters are the only solidstate fuel cells, allowing different designs and a broad range of applications. Moreover, the high operation temperatures ensure high efficiencies and the possibility of internal processing of different fuels [2-5].

A standard SOFC consists basically of two porous electrodes, typically yttria-stabilized zirconia (YSZ) - Ni cermet anode and strontium-doped lanthanum manganite (LSM) cathode, separated by a dense YSZ electrolyte [1,6]. Such a ceramic fuel cell requires controlled and cost effective processing techniques for fabrication. Several techniques have been reported for SOFC electrode and electrolyte depositions and, essentially, they can be divided in two main categories: wet chemistry and physical processes $[7,8]$. The later ones have great reproducibility, but the high costs can be an issue. Wet chemistry techniques are preferred for industrial production, but require a detailed control to ensure reproducibility $[7,8]$.

Amongst wet chemistry deposition techniques, possibly, the most developed ones are screen printing and wet spray [7-9]. However, spin coating has gained attention as a method to produce thin layers for SOFCs, which can be used for layer depositions for both electrolyte- and anode-supported cells [10-19]. Such technique is based on the deposition by rotation in which a suspension is spread across the surface of a substrate by a centrifugal acceleration. It is a widely used technique in the electronic industry, in microlithography for the manufacture of integrated circuits and for fabrication of antireflective coatings in solar cells [1019]. Spin coating has been successfully developed to fabricate both porous electrode layers and dense electrolyte films for anode supported SOFCs, evidencing the suitability of such deposition technique [10-19].

In the present study a systematic development of spin-coated SOFC electrodes is reported. The optimum conditions for preparing electrolyte-supported single cells with uniform microstructure and good electrochemical performance were determined by investigating the main microstructural parameters of both cathode and anode layers. 


\section{MATERIALS AND METHODS}

The $\mathrm{La}_{0.65} \mathrm{Sr}_{0.30} \mathrm{MnO}_{3}$ (LSM) cathode was synthesized by the polymeric precursor technique [20]. Starting materials were $\mathrm{La}\left(\mathrm{NO}_{3}\right)_{2} \cdot 6\left(\mathrm{H}_{2} \mathrm{O}\right)$ (Aldrich, 99,99\%), $\mathrm{Sr}\left(\mathrm{NO}_{3}\right)_{3} \cdot 4\left(\mathrm{H}_{2} \mathrm{O}\right)$ (Aldrich, 99\%), $\mathrm{Mn}\left(\mathrm{CH}_{3} \mathrm{CO}_{3}\right)_{2} .4\left(\mathrm{H}_{2} \mathrm{O}\right)$ (Aldrich, 99\%). Citric acid (Fluka, 99.5\%) was added to an aqueous solution of the metallic salts under constant mixing and heated at $\sim 70^{\circ} \mathrm{C}$. Ethylene glycol (Aldrich, $99.8 \%$ ) was added and the resulting solution was kept under constant mixing and heating $\left(70^{\circ} \mathrm{C}\right)$ until a viscous resin was obtained. The polymeric precursor was heat treated at $300^{\circ} \mathrm{C}$ and calcined at $800^{\circ} \mathrm{C}$ to obtain single phase LSM. The calcining time at $800^{\circ} \mathrm{C}$ was varied between $1 \mathrm{~h}$ and $3 \mathrm{~h}$. Composite LSM-YSZ (50-50 wt.\%) for the cathode functional layer (FL) was prepared by mixing YSZ (Tosoh, Japan) and LSM powders. The powders were suspended in ethanol and ball milled for $16 \mathrm{~h}$ with zirconia ball (TZ-3Y, Tosoh, $8 \mathrm{~mm}$ diameter). After milling, ethanol was evaporated under mixing at $100^{\circ} \mathrm{C}$.

The NiO-YSZ composite powders were prepared by a liquid mixture method [21]. Such a method consists in the evaporation of a dispersion of YSZ in nickel acetate (Aldrich, 99\%) solution in ethanol under mixing and heating at $70^{\circ} \mathrm{C}$, followed by calcining at $450^{\circ} \mathrm{C}$ for $5 \mathrm{~h}$. NiO-YSZ composites were prepared in two different proportions aiming at final Ni-YSZ anode compositions 40-60 vol.\%, for the functional layer (FL), and 60-40 vol.\%, for the current-collector layer (CL). For both the cathode and the anode FL powders, the effect of particle size distribution was investigated after a ball milling step for $16 \mathrm{~h}$ using YSZ grinding media.

Crystalline phases were investigated by X-ray diffraction (XRD, Rigaku Miniflex), in the $20^{\circ}-80^{\circ} 2 \theta$ range, with step size $0.05^{\circ}$ and $2 \mathrm{~s}$ counting time/step, using $\mathrm{Cu} \mathrm{K}_{\alpha}$ radiation. Particle size distributions were determined by laser scattering.

Electrolyte-supported single solid oxide fuel cells were fabricated for testing different electrodes. Firstly, yttria-stabilized zirconia ( $8 \mathrm{~mol} \%$, YSZ - Tosoh) substrates were prepared by uniaxial pressing ( 1 ton $\mathrm{cm}^{-2}$ ), pre-sintering at $1500{ }^{\circ} \mathrm{C}$, diamond wheel grinding, and sintering at $1600^{\circ} \mathrm{C}$ for $1 \mathrm{~h}$ in air. Final dimensions of YSZ supports are $\sim 20 \mathrm{~mm}$ diameter and $\sim 500 \mu \mathrm{m}$ thickness. Anodic and cathodic layers were deposited by spin-coating. The suspensions for spin coating, with $30 \%$ solids loading, were prepared by dissolving ethyl cellulose in Terpineol (Aldrich) under constant mixing and heating at $80^{\circ} \mathrm{C}$. After cooling to room temperature, the ceramic powder (LSM, LSM-YSZ, or NiO-YSZ) was added to the solution and mixed for $15 \mathrm{~h}$ in a ball mill with zirconia balls grinding media. Suspensions for spin coating were developed aiming at simple preparation and fast deposition with a minimum spin coating steps to achieve the desired layer thickness $(t)$. The YSZ substrate is fixed to the spin coater (Laurel, model WS-400-6NPP-LITE) by vacuum. The ceramic suspension was deposited onto the substrate, and rotated at $6000 \mathrm{rpm}$ for $10 \mathrm{~s}$. For typical electrode thickness two spin coating steps were performed. After coating, the deposited layer is dried in a hot plate at $80^{\circ} \mathrm{C}$ for $5 \mathrm{~min}$. The active area of the single cells is $0.78 \mathrm{~cm}^{2}(1 \mathrm{~cm}$ diameter).

The fabricated single cells have both the anode and the cathode comprised of two layers: the functional layer (FL), which is the interfacial layer deposited on the electrolyte, and the current-collector layer (CL), deposited over the FL. Cathode and anode FL were LSM-YSZ (50-50 wt.\%) and YSZ-NiO (60-40 vol.\%) composites, respectively. The CL for the cathode and anode was LSM and the YSZ-NiO (40-60 vol.\%), respectively. Fig. 1 shows the scheme of the electrolyte supported single cells. Layer thickness of both FL and CL were controlled by the suspension mass deposited and the number of deposition steps on the spin coater. Each layer typically requires 2 to 3 spin coating steps to attain desired thickness. Hereafter, the thickness of the electrode layers refer to the nominal values, unless otherwise indicated in the text. The thickness of electrode layers and sintering temperatures were varied in order to optimize the performance of single cells. Typically, FL (anode and cathode) were varied between $t=10-30 \mu \mathrm{m}$ and the CL (anode and cathode) between $t$ $=20-80 \mu \mathrm{m}$. Sintering temperatures were in the $1100-1200^{\circ} \mathrm{C}$ and $1300-1400^{\circ} \mathrm{C}$ temperature ranges, for cathode and anode, respectively. Such values are within the typical temperature range used for sintering SOFCs electrodes aiming at reduced costs and optimized microstructures [1].

The microstructural characterization of the samples was performed by scanning electron microscopy (SEM, Jeol JSM-6010LA) of the cross section of fractured surfaces sputtered with Pt.

The performance of single cells was evaluated by measuring the polarization curves (I-V) and impedance spectroscopy (IS) in the temperature range of $600-800^{\circ} \mathrm{C}$. The electrical contact was a $\mathrm{Pt}$ mesh attached to both the anode and cathode with $\mathrm{Pt}$ paste cured at $800^{\circ} \mathrm{C}$ for $1 \mathrm{~h}$. Samples were sealed on one side of an alumina tube with Aremco 552 cement, followed by curing accordingly to the supplier's manual. The alumina tube contains inside alumina capillary tubes for both fuel deliver and two Pt wires for anode electrical contacts. The alumina tube is placed inside a quartz tube in a horizontal split resistive furnace. The tubes are connected to external flanges that support separated gas inlet/outlet and two contact terminals for both cath- 
ode and anode side. Single cells were tested with $\mathrm{H}_{2}\left(3\right.$ vol. $\left.\% \mathrm{H}_{2} \mathrm{O}\right)$ and synthetic air, both with flow rates of $50 \mathrm{~mL} \mathrm{~min}{ }^{-1}$ set by mass flow controllers. A multichannel digital multimeter (Keithley 2000) monitors both the emf of a type $\mathrm{K}$ thermocouple placed close to the cathode and the ambient temperature of an electronic sensor. The main fuel cell parameters are controlled, stored, and monitored on a LabView based software, by connecting both the mass flow controllers and the multimeter to a microcomputer via GPIB (National Instruments) interface. The I-V and IS data were measured using a Zahner IM-6 electrochemical station. I-V curves were collected with a $10 \mathrm{mV} \mathrm{min}^{-1}$ rate, from the open circuit voltage (OCV $\sim 1.1 \mathrm{~V}$ ) to $0.2 \mathrm{~V}$. IS data were measured at OCV with $100 \mathrm{mV}$ ac amplitude, in the $0.1 \mathrm{~Hz}$ to $1 \mathrm{MHz}$ interval. All samples were measured in duplicates, and in some cases a third sample was fabricated and measured to confirm results.

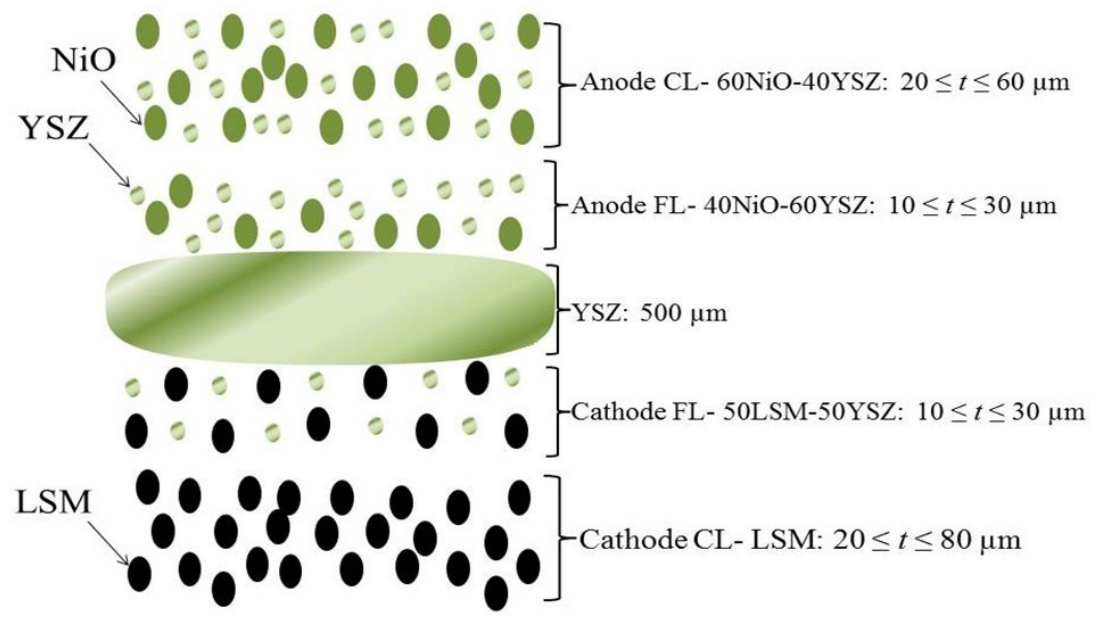

Figure 1: Schematics of the layers of the single SOFC (not in scale): anode ( $\mathrm{CL}=$ current collector and $\mathrm{FL}=$ functional layer), electrolyte support, and cathode (CL and FL). Thickness $(t)$ of each layer is indicated.

\section{RESULTS AND DISCUSSION}

\subsection{Characterization of starting materials}

The LSM powders calcined at $800^{\circ} \mathrm{C}$ for $1 \mathrm{~h}$ and $3 \mathrm{~h}$ were analyzed by XRD, as shown in Fig. 2. The XRD patterns evidenced LSM single phase for both calcining times. The diffraction peaks of LSM were indexed based on the ICSD 70-2775, with rhombohedral symmetry. The unit-cell parameters calculated from the XRD data are within the experimental error: $a=b=c=5.5211$ (62) $\AA$ and $a=b=c=5.5293$ (53) $\AA(\alpha=$ $\beta=\gamma=120^{\circ}$ ) for the sample calcined for $1 \mathrm{~h}$ and $3 \mathrm{~h}$, respectively. Such values are in good agreement with previous reported results $[22,23]$. 


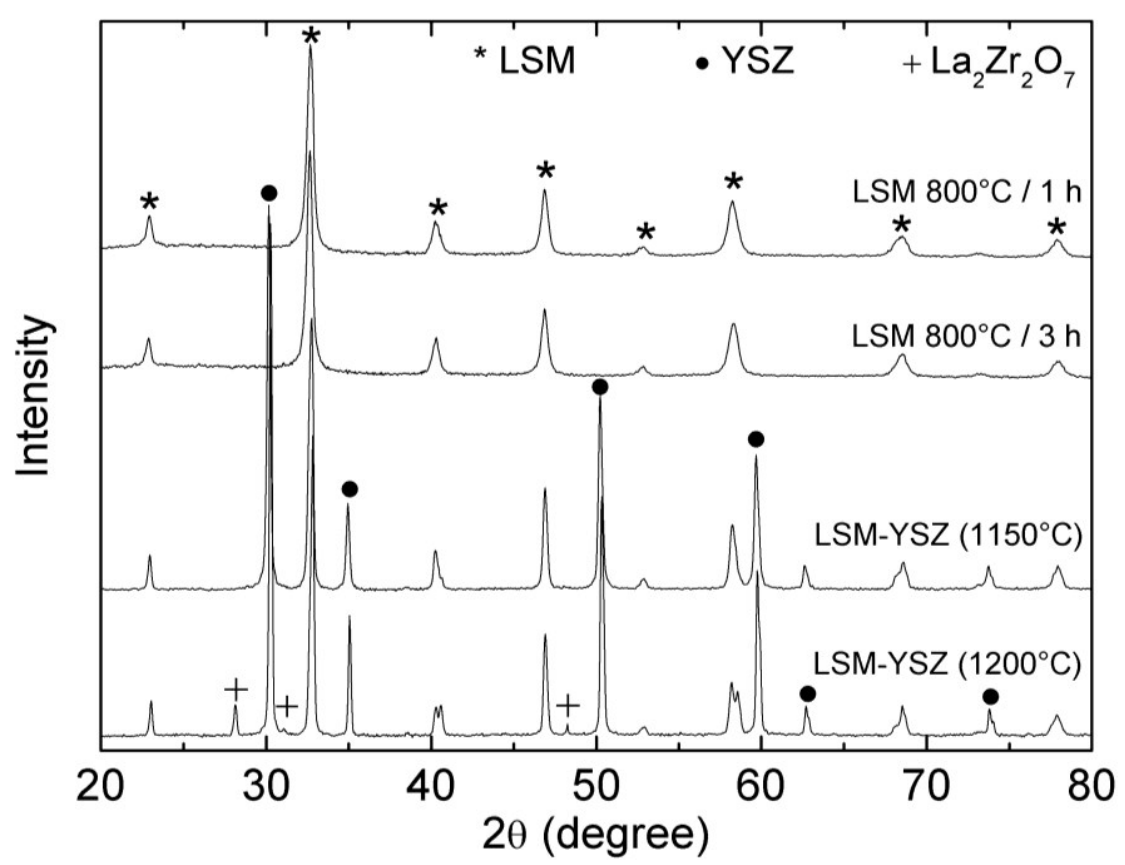

Figure 2: X-rays diffraction patterns of LSM calcined at $800^{\circ} \mathrm{C}$ for $1 \mathrm{~h}$ and $3 \mathrm{~h}$.

The XRD patterns of LSM-YSZ composite powders heat treated at $1150^{\circ} \mathrm{C}$ and $1200^{\circ} \mathrm{C}$ were analyzed (Fig. 2). The composite samples heated at $1150^{\circ} \mathrm{C}$ showed diffraction peaks of both LSM and YSZ phases. However, XRD results of the LSM-YSZ sample heated at $1200^{\circ} \mathrm{C}$ shows peaks corresponding to secondary phases. The formation of resistive phases such as lanthanum zirconate $\left(\mathrm{La}_{2} \mathrm{Zr}_{2} \mathrm{O}_{7}\right)$, or strontium zirconate $\left(\mathrm{SrZrO}_{3}\right)$, is well-known to occur at temperatures higher than $\sim 1150^{\circ} \mathrm{C}$ [22-24].

The XRD patterns of NiO-YSZ (40-60 and 60-40 vol.\%) composites are shown in Fig. 3. Only peaks corresponding to the cubic structures of YSZ and $\mathrm{NiO}$ were observed. The XRD patterns were indexed based on the JCPDS cards 7-1049 (NiO) and 30-1468 (YSZ).

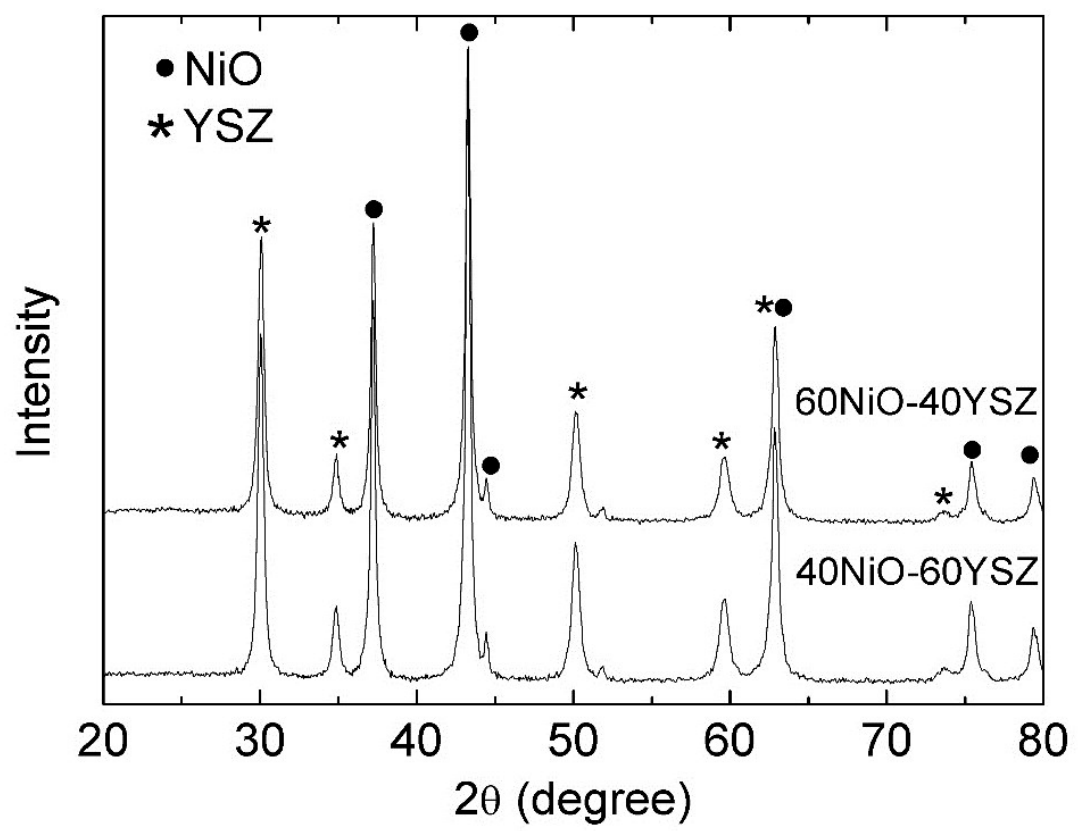

Figure 3: X-rays diffraction patterns of NiO-YSZ anode precursors after calcining at $450^{\circ} \mathrm{C}$. Symbols $*$ and $\bullet$ mark the diffraction peaks of YSZ and $\mathrm{NiO}$, respectively. 
The produced powders were processed for the preparation of ceramic suspensions for electrode depositions by spin coating. An important parameter was the particle (or agglomerate) size distribution, which was controlled by a ball milling step. Table 1 lists the main parameters of the particle size distributions extracted from the light scattering experiments.

Table 1: Characteristic diameters determined from particle/agglomerate size distribution analysis.

\begin{tabular}{cccc}
\hline Material & \multicolumn{3}{c}{ Particle Diameter $(\boldsymbol{\mu m})$} \\
\cline { 2 - 4 } & $\mathbf{d}_{\mathbf{1 0}}$ & $\mathbf{d}_{\mathbf{5 0}}$ & $\mathbf{d}_{\mathbf{9 0}}$ \\
\hline 40NiO-60YSZ (as-prepared) & 0.73 & 2.7 & 16.5 \\
40NiO-60YSZ (milled) & 0.55 & 1.4 & 4.6 \\
60NiO-40YSZ (as-prepared) & 0.74 & 1.9 & 16.8 \\
$\mathrm{LSM}\left(800^{\circ} \mathrm{C} / 1 \mathrm{~h}\right)$ & 2.9 & 19.7 & 55.9 \\
$\mathrm{LSM}\left(800^{\circ} \mathrm{C} / 3 \mathrm{~h}\right)$ & 0.27 & 3.5 & 10.7 \\
$\mathrm{LSM}\left(800^{\circ} \mathrm{C} / 1 \mathrm{~h}\right)+\mathrm{YSZ}$ & 0.56 & 3.1 & 11.9 \\
$\mathrm{LSM}\left(800^{\circ} \mathrm{C} / 3 \mathrm{~h}\right)+\mathrm{YSZ}$ & 0.14 & 1.3 & 10.2 \\
$\mathrm{LSM}\left(800^{\circ} \mathrm{C} / 3 \mathrm{~h}\right)+\mathrm{YSZ}(\mathrm{milled})$ & 0.52 & 1.2 & 4.8 \\
\hline
\end{tabular}

The characteristic diameters of both FL and CL anode layers were equivalent, irrespectively of the relative phase composition. The ball milling step for the anode FL precursor powder resulted in a considerable reduction of the mean particle size $\mathrm{d}_{50}$ from 2.7 to $1.4 \mu \mathrm{m}$. Moreover, milling resulted in a significant narrowing of the particle size distribution, as inferred from $\mathrm{d}_{90} / \mathrm{d}_{10}$ ratio decrease from 22 to 8 . Particle distribution analysis of cathode powders revealed an unexpected dependence on the calcining time. The LSM powder calcined at $800^{\circ} \mathrm{C}$ for $1 \mathrm{~h}$ exhibited a $\mathrm{d}_{50} \sim 19 \mu \mathrm{m}$, while powder calcined for $3 \mathrm{~h}$ displayed significantly decreased mean particle size $\left(\mathrm{d}_{50} \sim 3.5 \mu \mathrm{m}\right)$. Crystallite diameter estimated by using the Scherrer equation and XRD data showed weak dependence on the calcining time, increasing from $16 \mathrm{~nm}$ to $18 \mathrm{~nm}$ with increasing time from $1 \mathrm{~h}$ to $3 \mathrm{~h}$, respectively. Such behavior was further investigated by thermogravimetric (TG) analysis (not shown), which evidenced that powder calcined at $800^{\circ} \mathrm{C}$ for $1 \mathrm{~h}$ exhibited a 3.5\% mass loss up to $800^{\circ} \mathrm{C}$. Thus, calcining time of 1 hour was insufficient to remove the organic residues from synthesis. Therefore, particle size measurements for such material include both the organic residue and the inorganic phase. Calcining powder for 3 hours resulted in pure LSM and particle size measurements reflect the average particle of the cathode precursor powder. Milling the cathode FL powder significantly narrowed the particle size distribution by decreasing $\mathrm{d}_{90}$ from $\sim 10$ to $5 \mu \mathrm{m}$.

\subsection{Fuel cell optimization}

The first parameter to be investigated was the thickness of the electrode layers (FL and CL). Initially, a series of single cells was fabricated with fixed FL thickness $(20 \mu \mathrm{m})$ of both anode and cathode. Then, the CL thickness was varied between $20 \mu \mathrm{m}$ and $80 \mu \mathrm{m}$ (cathode) and between $20 \mu \mathrm{m}$ and $60 \mu \mathrm{m}$ (anode). Figure 4 shows the I-V curves for samples with different thickness of the CL layers for the cathode (Fig. 4a) and for the anode (Fig. 4b).

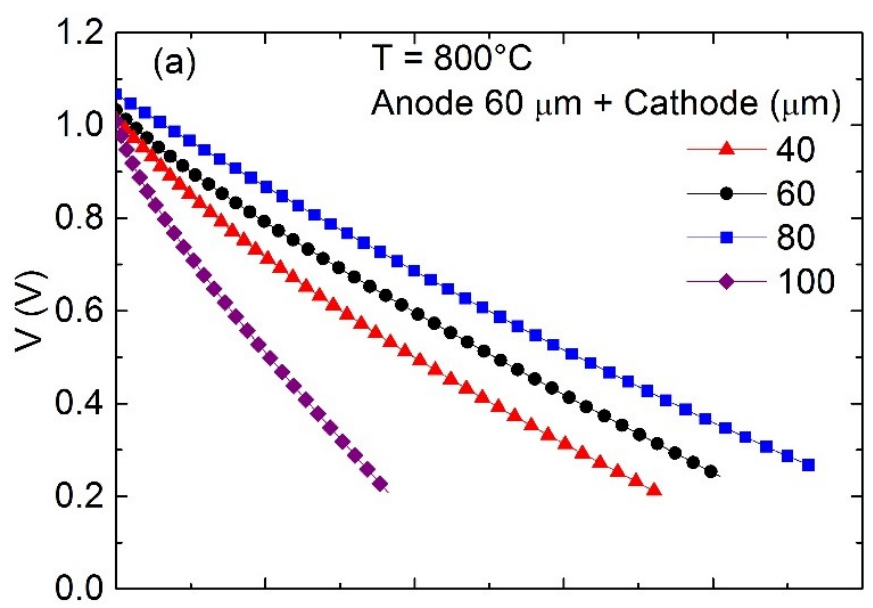




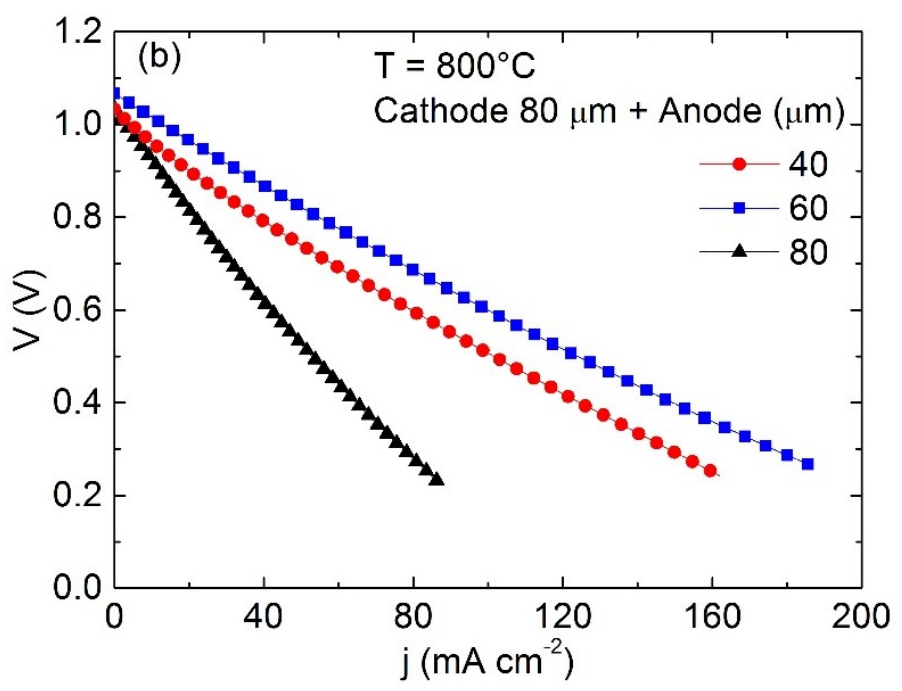

Figure 4: Polarization curves at $800^{\circ} \mathrm{C}$ of single cell with fixed FL thickness $(20 \mu \mathrm{m})$ and different CL layers for the (a) cathode and (b) anode. The indicated thickness corresponds to the total electrode thickness: FL $(20 \mu \mathrm{m})+\mathrm{CL}$.

The experimental data shown in Fig. 4 indicated that by fixing the anode thickness at 60 (FL $=20 \mu \mathrm{m}$, $\mathrm{CL}=40 \mu \mathrm{m})$ and increasing the thickness of the cathode CL from $40 \mu \mathrm{m}$ to $80 \mu \mathrm{m}$ increased the fuel cell performance, reaching a maximum current density of $\sim 100 \mathrm{~mA} \mathrm{~cm}^{-2}$ at $0.6 \mathrm{~V}$. However, further increasing the cathode $\mathrm{CL}$ to $100 \mu \mathrm{m}$ resulted in a rapid decrease of the performance. By using the optimized thickness of the cathode, the anode CL was varied from $40 \mu \mathrm{m}$ to $80 \mu \mathrm{m}$ (Fig. 4b). Similarly to the cathode behavior, maximum performance was observed for an intermediary value $(t=60 \mu \mathrm{m})$. Such behavior is related to a maximum thickness that minimizes both the electrical resistivity and the resistance to the transport of gaseous species through the CL layer to reaction sites at the triple phase boundary along FL/electrolyte interface [25-28].The performance of both electrodes was found to be strongly dependent on the thickness of the electrodes and such result is in agreement with previously reported experimental data and theoretical calculations [25-28].

By setting the anode CL thickness at $40 \mu \mathrm{m}$, the influence of FL thickness was studied. Fig. 5 shows the I-V curves of single cells with anode FL thickness between $10 \mu \mathrm{m}$ and $30 \mu \mathrm{m}$, and fixed CL layer (40 $\mu \mathrm{m})$. Similarly to the CL (Fig. 4), the thickness of the FL has a marked influence on the performance of single cells. Such dependence is related to an optimal thickness that corresponds to the balance between the ohmic resistance and triple phase boundary length [25-30]. Considering that the microstructure (average grain size and porosity) of the FL is essentially independent on the FL thickness, it is possible to point out some features. For FL thickness $10 \mu \mathrm{m}$, the I-V curve shows a nonlinear portion at low current densities that indicates contribution from activation polarization, possibly due to limited triple phase boundaries length. On the other hand, for FL thickness $30 \mu \mathrm{m}$ a strong ohmic polarization, possibly due to a relatively thick FL, with low Ni content, rapidly decreases the fuel cell performance. The FL thickness $20 \mu \mathrm{m}$ exhibited a linear $\mathrm{I}-\mathrm{V}$ curve and the highest current output. 


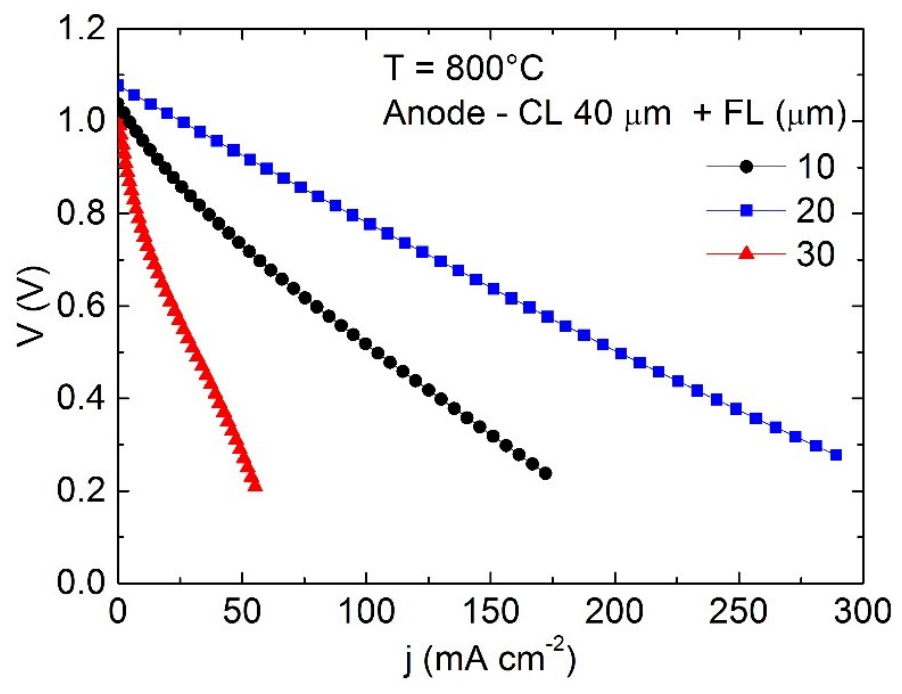

Figure 5: Polarization curves at $800^{\circ} \mathrm{C}$ of single cells with different anode FL layers and fixed CL (40 $\left.\mu \mathrm{m}\right)$.

Figure 6 shows SEM images of the different FL at the electrolyte/anode interface corresponding to the single cells results shown in Fig. 5. The thickness of FL was estimated by SEM images in Fig 6a-c: 12.4, 20.3, and $26.7 \mu \mathrm{m}$, respectively, in good agreement with nominal values. Moreover, SEM images indicate good adhesion of anode FL to the electrolyte and homogeneous surface across the interface. The SEM images confirm that it was possible to control the deposition of electrode layers by spin-coating.
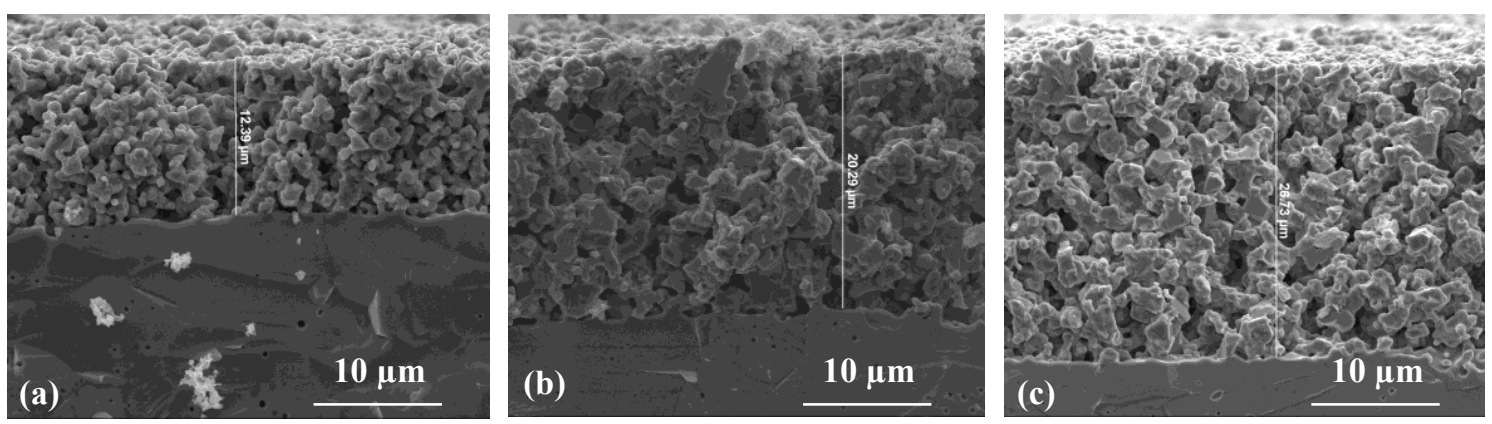

Figure 6: SEM images of the electrolyte / anode functional interface with anode FL thickness (a) $\sim 12 \mu \mathrm{m}$, (b) $\sim 20 \mu \mathrm{m}$, and (c) $\sim 27 \mu \mathrm{m}$.

Both the thickness and the microstructure are key parameters for enhancing the performance of fuel cells. Therefore, a detailed analysis of the sintering temperature of both the cathode and anode was carried out. Figures 7 and 8 show the I-V curves of single cells with cathodes sintered at different temperatures and the correspondent SEM images, respectively.

The results of Fig. 7 revealed that the sintering temperature $\left(\mathrm{T}_{\text {sint }}\right)$ is a critical parameter for fuel cell performance. The sintering temperature controls both the particle/pore size distributions and the adhesion of the electrode layer to the electrolyte support. For the cathode (Fig. 7), a maximum performance was observed for $\mathrm{T}_{\text {sint }}=1150^{\circ} \mathrm{C}$. Increasing $\mathrm{T}_{\text {sint }}$ to $1200^{\circ} \mathrm{C}$ is known to result in undesired reactions between LSM and YSZ that can form resistive phases on the cathode/electrolyte interface (Fig. 2) [31]. The SEM images of the fractured cross section of the cathode sintered at different temperatures are shown in Fig. 8. 


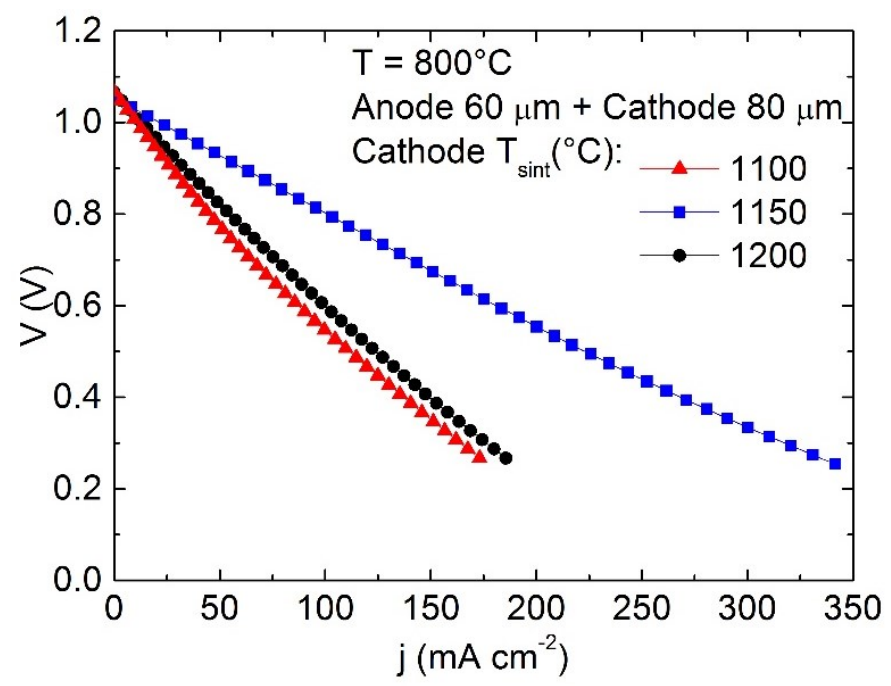

Figure 7: Polarization curves at $800^{\circ} \mathrm{C}$ of single cells with different cathode sintering temperatures.

Fig. 8 shows round-shaped grains with average size $<1 \mu \mathrm{m}$ for samples sintered up to $1150{ }^{\circ} \mathrm{C}$. Both the average grain size and interparticle connectivity significantly increased with increasing sintering temperature from 1100 to $1150{ }^{\circ} \mathrm{C}$, a feature closely related to the enhanced performance of the fuel cell sintered at $1150^{\circ} \mathrm{C}$ shown in Fig. 7. Further increasing $\mathrm{T}_{\text {sint }}$ to $1200^{\circ} \mathrm{C}$ resulted in significant microstructural changes, with larger grain size distribution and more faceted particles, probably reflecting the reaction between LSM and YSZ. Thus, controlling the cathode microstructure requires a careful control of the sintering temperature in a relatively narrow temperature interval.
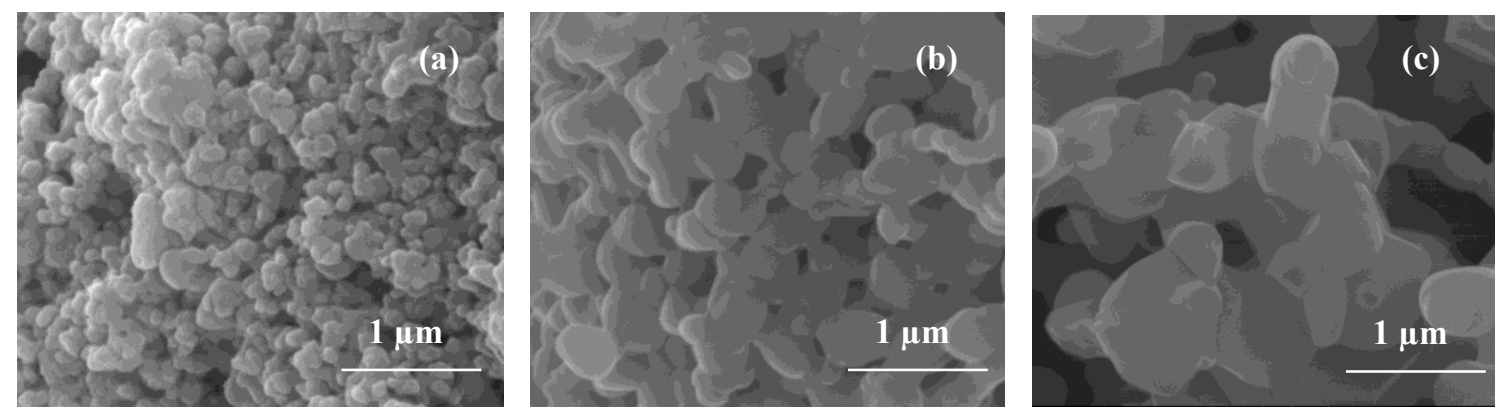

Figure 8: SEM images for the cathode sintered at different temperatures: (a) $1100^{\circ} \mathrm{C}$, (b) $1150^{\circ} \mathrm{C}$, and (c) $1200^{\circ} \mathrm{C}$.

Figure 9 shows the I-V curves of single cells with anodes sintered at different temperatures. For the anode a maximum performance was observed for $\mathrm{T}_{\text {sint. }}=1400^{\circ} \mathrm{C}$. Such a strong dependence of the sintering temperature is related to both the adhesion between the anode layers to the electrolyte and better connectivity between Ni particles, observed as a significant decrease of the ohmic polarization in the I-V curve. 


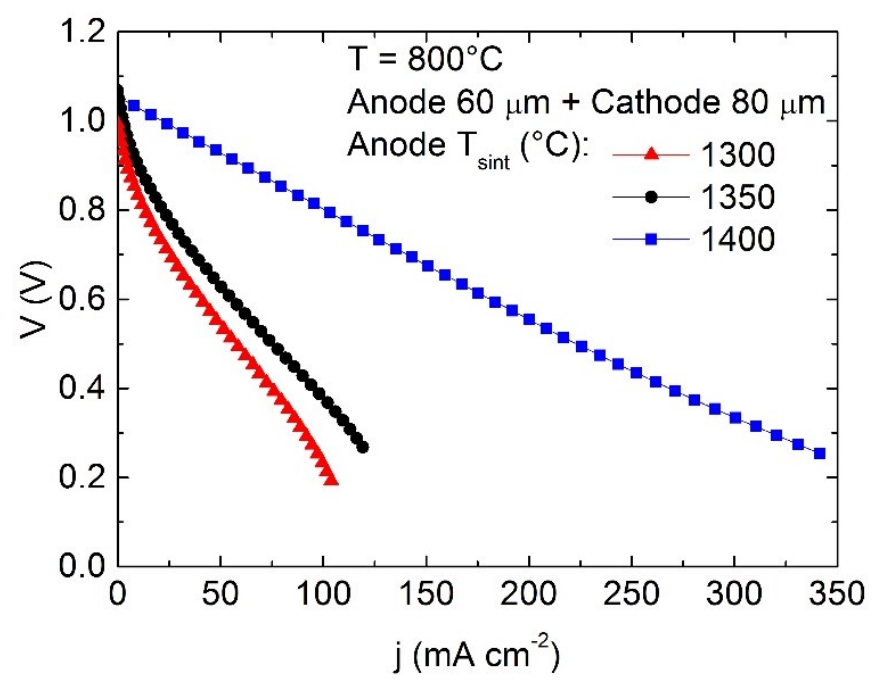

Figure 9: Polarization curves at $800^{\circ} \mathrm{C}$ of single cells with different anode sintering temperatures.

The cathode was further studied by varying the calcining temperature of the precursor powder. Fig. 10 shows the I-V curves of single cells with the LSM powder for both CL and FL calcined for different times. The curves indicated that increasing the calcination time from $1 \mathrm{~h}$ to $3 \mathrm{~h}$ decreases the polarization resistance of the cell. Such an effect is mainly observed in the ohmic loss region of the I-V curve and indicates that the complete removal of the organic residues of the LSM powder is important. The residual organics inhibit the sintering of the cathode and decreases the electronic conductivity of the electrode.

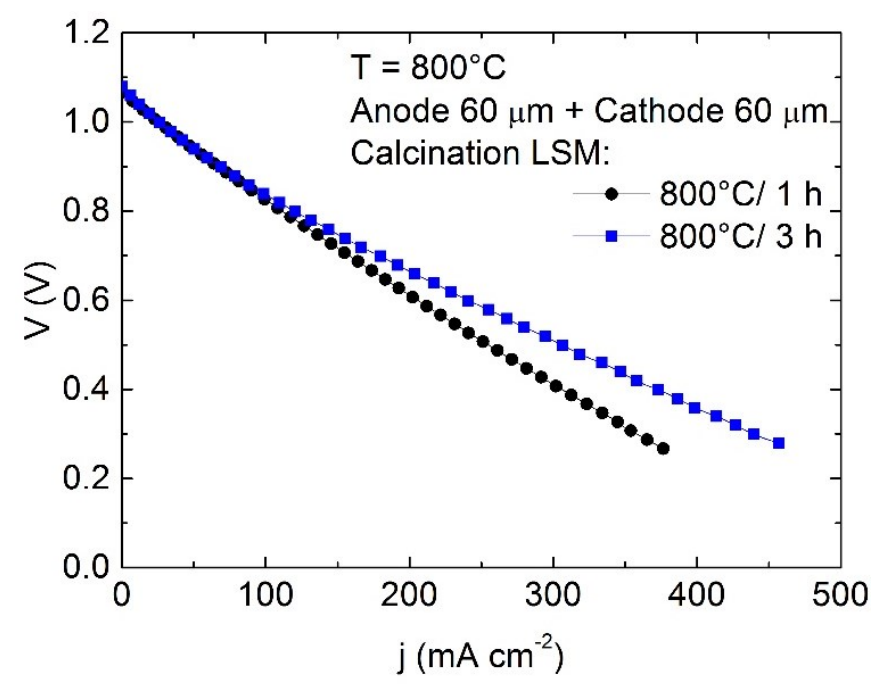

Figure 10: Polarization curves at $800{ }^{\circ} \mathrm{C}$ of single cells with LSM powders calcined for $1 \mathrm{~h}$ and $3 \mathrm{~h}$.

The effect of average grain size of both anode and cathode FL was investigated by milling the precursor powders. Fig. 11 compares the polarization curves for samples with FL's (40NiO-60YSZ and LSM-YSZ, for anode and cathode, respectively) using precursor powders with different particle size distributions, as listed in Table 1. Controlling particle size distribution has a marked effect on the I-V curve. It was possible to observe a significant increase in the performance of the single cells reflected as an increase of the OCV and reduced ohmic polarization. Such features are related to enhanced reaction mechanisms related to both increased triple boundary phase length and lower contact resistance due to increased surface area of electrodes FL. The current density at $0.6 \mathrm{~V}$ was substantially increased from $\mathrm{j} \sim 250 \mathrm{~mA} \mathrm{~cm}^{-2}$ to $\sim 360 \mathrm{~mA} \mathrm{~cm}{ }^{-2}$ after FL 
powder milling. Such an increased is reflected on the power density of the single cells shown in Fig. 11. Maximum power density displayed a significant increase from $\sim 150 \mathrm{~mW} \mathrm{~cm}^{-2}$ to $\sim 220 \mathrm{~mW} \mathrm{~cm}^{-2}$. Comparing power density values of fuel cells is a hard task due to different fabrication and measurement conditions used in reported studies. Nonetheless, the values obtained are comparable to previously reported data, but below the state-of-the-art fuel cells, which usually have thin YSZ supports $(\sim 150 \mu \mathrm{m})$ and can exceed $1 \mathrm{~W} \mathrm{~cm}^{-2}$ in similar testing conditions [32,33].

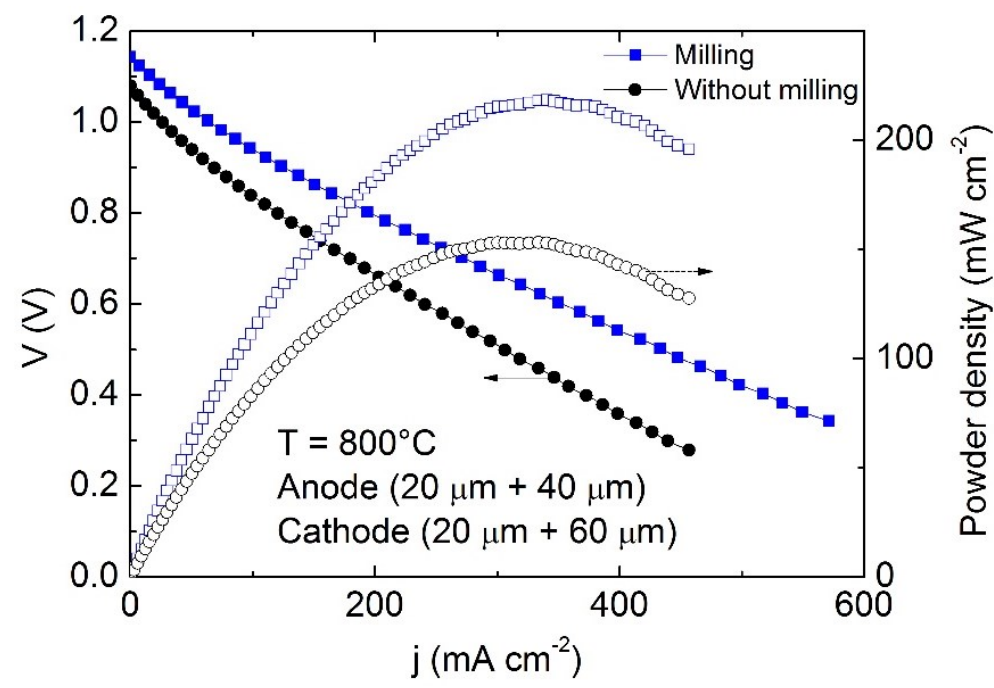

Figure 11: Polarization (left y-axis) and power density (right y-axis) curves at $800{ }^{\circ} \mathrm{C}$ showing the effect of milling anode and cathode FL powders.

In order to investigate the effect of the microstructural optimization of electrodes IS data of different fuel cells were measured at OCV. Figure 12 compares the impedance diagrams corresponding to the optimized fuel cell (Fig. 11) with non-optimized fuel cell (Fig. 5).

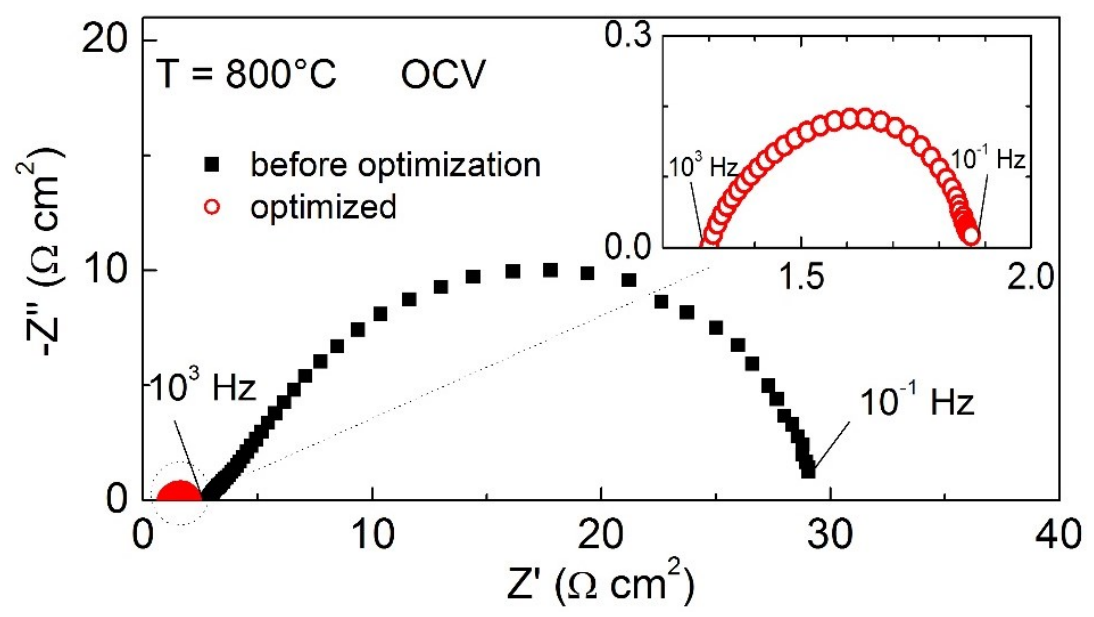

Figure 12: Impedance diagrams of single SOFCs before and after microstructural optimization. The inset shows the expanded view of data corresponding to the optimized electrodes.

The single cell with best performance was the one with nominal thickness of anode FL $20 \mu \mathrm{m}+\mathrm{CL}$ $40 \mu \mathrm{m}$, sintered at $1400^{\circ} \mathrm{C}$, and cathode FL $20 \mu \mathrm{m}+\mathrm{CL} 60 \mu \mathrm{m}$, sintered at $1150^{\circ} \mathrm{C}$, both having controlled particle size distributions (Table 1 and Fig. 11). The impedance diagrams of Fig. 12 summarize the main result of this study. The experimental results revealed a significant decrease of the electrode polarization resistance from $\sim 26 \Omega \mathrm{cm}^{2}$ to $\sim 0.6 \Omega \mathrm{cm}^{2}$. Such a decrease was achieved by both adjusting electrode thickness and tuning the microstructure of electrodes. It is important to consider the performance of single cells report- 
ed in this study to be limited by both the electrolyte thickness $(\sim 500 \mu \mathrm{m})$ and the relatively low operating temperature for LSM cathodes. Nonetheless, measured values indicate that further development is required to attain lower polarization resistances and enhanced fuel cell performance. Such developments are underway.

\section{CONCLUSIONS}

A systematic optimization of the microstructure of spin-coated electrodes in electrolyte supported solid oxide fuel cell was carried out. The main results confirmed that processing of precursor powders along with careful control of cell fabrication are key parameters for achieving low polarization resistance. A decrease of circa two orders of magnitude of the electrode polarization resistance resulted in significant performance enhancement of single cells. Such results indicate that spin coating can be used as a fast and cost effective technique for deposition of solid oxide fuel cell electrodes.

\section{ACKNOWLEDGEMENTS}

Authors are thankful for the partial financial support of FINEP, CNPq, Fapesp 2013/26961-7, 2014/09087-4, and CNEN. Authors are thankful to CAPES (SDN and NKM) for scholarships. FCF and DFZ are CNPq fellows.

\section{BIBLIOGRAPHY}

[1] MINH, N.Q. “Ceramic fuel cells”, Journal of The American Ceramic Society, v. 76, pp. 563-588, 1993.

[2] ATKINSON, A., BARNETT, S., GORTE, R.J., et al., “Advanced anodes for high-temperature fuel cells”, Nature Materials, v. 3, pp. 17-27, 2004.

[3] LIU, J., BARNETT, S.A. "Operation of anode-supported solid oxide fuel cells on methane and natural gas”, Solid State Ionics, v. 158, pp. 11-16, 2003.

[4] ZHAN, Z., BARNETT, S.A. "Solid oxide fuel cells operated by partial oxidation reforming of isooctane”, Journal of Power Sources, v. 155, pp. 353-357, 2006.

[5] LIAO, M., WANG, W., RAN, R., et al., "Development of a Ni-Ce ${ }_{0.8} \mathrm{Zr}_{0.2} \mathrm{O}_{2}$ catalyst for solid oxide fuel cells operating on ethanol through internal reforming", Journal of Power Sources, v. 196, pp. 6177-6185, 2011.

[6] FLORIO, D.Z., FONSECA, F.C., MUCCILLO, E.N.S., et al., "Materiais cerâmicos para células as combustível", Cerâmica, v. 50, pp. 275-290, 2004.

[7] SCUEGRAF, K.K. Handbook of thin film deposition processes and techniques (Materials and processing technology), William Andrew, 2002.

[8] WINCEWICZ, K.C., COOPER, J.S. "Taxonomies of SOFC material and manufacturing alternatives", Journal of Power Sources, v. 140, pp. 280-296, 2005.

[9] MINH, N.Q. "Solid oxide fuel cell technology—features and applications", Solid State Ionics, v. 174, pp. 271 - 277, 2004.

[10] SMITH, D.L. Thin-film deposition: Principles \& Practice, McGraw-Hill Professional, 1995.

[11] NOBREGA, S.D., GALESCO, M.V., GIRONA, K., et al., "Direct ethanol solid oxide fuel cell operating in gradual internal reforming”, Journal of Power Sources, v. 213, pp. 156 - 159, 2012.

[12] MONTEIRO, N.K., NORONHA, F.B., COSTA, L.O.O., et al., "A direct ethanol anode for solid oxide fuel cell based on a chromite-manganite with catalytic ruthenium nanoparticles", International Journal of Hydrogen Energy, v. 37, pp. 9816 - 9829, 2012.

[13] XU, X., XIA, C., HUANG, S., et al., "YSZ thin films deposited by spin-coating for IT-SOFCs", Ceramics International, v. 31, pp. 1061 - 1064, 2005.

[14] WANG, J., LU, Z., CHEN, K., et al., "Study of slurry spin coating technique parameters for the fabrication of anode-supported YSZ films for SOFCs”, Journal of Power Sources, v. 164, pp. 17 - 23, 2007.

[15] HUI, R., WANG, Z., YICK, S., et al., "Fabrication of ceramic films for solid oxide fuel cells via slurry spin coating technique", Journal of Power Sources, v. 172, pp. 840 - 844, 2007.

[16] TABUTI, F.N., FONSECA, F.C., FLORIO, D.Z. "Desenvolvimento e testes de células a combustível suportadas pelo anodo com eletrólitos depositados por spin-coating”, Matéria, v. 18, pp. 39 - 45, 2013.

[17] SUN, H.Y., SEN, W., MA, W.H., et al., "Fabrication of LSGM thin films on porous anode supports by slurry spin coating for IT-SOFC”, Rare Metals, v. 34, pp. 797-801, 2015. 
[18] XIE, H., SU, P.-C. "Fabrication of yttrium-doped barium zirconate thin films with sub-micrometer thickness by a sol-gel spin coating method", Thin Solid Films, v. 584, pp. 116-119, 2015.

[19] KIMA, H.J., KIMA, M., NEOHA, K.C., et al.,"Slurry spin coating of thin film yttria stabilized zirconia/gadolinia doped ceria bi-layer electrolytes for solid oxide fuel cells”, Journal of Power Sources, v. 327, pp. 401-407, 2016.

[20] FONSECA, F.C, MUCCILLO, R. "Properties of $\mathrm{YBa}_{2} \mathrm{Cu}_{3} \mathrm{O}_{7-\delta}-\mathrm{Ag}$ superconductors prepared by the citrate method", Physica C: Superconductivity and its Applications, v. 267, pp. 87 - 92, 1996.

[21] FONSECA, F.C., FLORIO, D.Z., ESPOSITO, V., et al., "Mixed ionic-electronic YSZ/Ni composite for SOFC anodes with high electrical conductivity", Journal of The Electrochemical Society, v. 153 (2), pp. A354 - A360, 2006.

[22] DHAHRI, J., SEMNI, K., OUMEZZINE, M., et al., "The effect of deficit of strontium on structural, magnetic and electrical properties of $\mathrm{La}_{0.8} \mathrm{Sr}_{0.2-\mathrm{x}} \mathrm{MnO}_{3}$ manganites", Journal of Alloy and Compounds, v. 394, pp. $51-57,2005$.

[23] ZEMNI, S., GASMI, A., BOUDARD, M., et al., "Effect of nominal strontium deficiency on the structure and the magnetic properties of $\mathrm{La}_{0.6} \mathrm{Sr}_{0.4-\delta} \mathrm{MnO}_{3}$ manganese perovskites", Material science and Engineering B, v. 144, pp. $117-122,2007$.

[24] JIANG, S.P. "Development of lanthanum strontium manganite perovskite cathode materials of solid oxide fuel cells: a review", Journal of Materials Science, v. 43, pp. 6799-6833, 2008.

[25] MURRAY, E.P., TSAI, T., BARNETT, S.A. "Oxygen transfer processes in ( $\mathrm{La}, \mathrm{Sr}) \mathrm{MnO}_{3} / \mathrm{Y}_{2} \mathrm{O}_{3}$ stabilized $\mathrm{ZrO}_{2}$ cathodes: an impedance spectroscopy study”, Solid State Ionics, v. 110, pp. 235-243, 1998.

[26] VIRKAR, A.V., CHEN, J., TANNER, C.W., et al., "The role of electrode microstructure on activation and concentration polarizations in solid oxide fuel cells”, Solid State Ionics, v. 131, pp. 189-198, 2000.

[27] HAANAPPEL, V.A.C., MERTENS, J., RUTENBECK, D., et al., "Optimization of processing and microstructural parameters of LSM cathodes to improve the electrochemical performance of anode-supported SOFCs", Journal of Power Sources, v. 141, pp. 216-226, 2005.

[28] CHEN, D., LIN, Z., ZHU, H., KEE, R.J. "Percolation theory to predict effective properties of solid oxide fuel-cell composite electrodes”, Journal of Power Sources, v. 191, pp. 240-252, 2009.

[29] KLEITZ, M., PETIBON, F. “Optimized SOFC electrode microstructure”, Solid State Ionics, v. 92, pp. 65-74, 1996.

[30] JIANG, S.P., CHAN, S.H. "A review of anode materials development in solid oxide fuel cells", Journal of Materials Science, v. 39, pp. 4405-4439, 2004.

[31] BRANT, M.C., DESSEMOND, L. "Electrical degradation of LSM-YSZ interfaces", Solid State Ionics, v. 138, pp. 1-17, 2000.

[32] BUCCHERI, M.A., SINGH, A., HILL, J.M. “Anode- versus electrolyte-supported Ni-YSZ/YSZ/Pt SOFCs: Effect of cell design on OCV, performance and carbon formation for the direct utilization of dry methane", Journal of Power Sources, v. 196, pp. 968-976, 2011.

[33] GLAUCHE, A., BETZ, T., MOSCH, S., et al., "Long-term, Redox and Thermal Cycling Stability of Electrolyte Supported Cells”, ECS Transactions, v. 25, pp. 411-419, 2009. 